Artikel Riset

DOI : 10.33751/jf.v9i2.1605
Fitofarmaka Jurnal Ilmiah Farmasi

Vol.9, No.2, Desember 2019 : 138-143

p-ISSN : 2087-9164 e-ISSN : 2622-755X

\title{
PENGEMBANGAN FORMULASI GEL YANG MENGANDUNG SISTEM TRANSFERSOME EKSTRAK DAUN PANDAN (Pandanus amaryllifolius)
}

\author{
Rini Ambarwati ${ }^{*}$, Yulianita \\ Program Studi Farmasi, Fakultas Matematika dan Ilmu Pengetahuan Alam \\ Universitas Pakuan Bogor, PO Box 452 Bogor 16143 \\ West Java, Indonesia \\ *E-mail: riniambarwati2507@gmail.com
}

Diterima : 12 November 2019 Direvisi : 7 Desember 2019 Disetujui : 12 Desember 2019

\begin{abstract}
ABSTRAK
Transfersome saat ini telah menjadi tren baru dalam pengembangan sistem penghantaran obat. Transfersome mempunyai kemampuan untuk dapat berpenetrasi ke dalam kulit lebih baik dibandingkan obat lain. Kulit yang mengalami Luka bakar mengalami kerusakan yang mempersulit proses penetrasi obat ke dalam kulit sehingga memperlama proses penyembuhan. Salah satu bahan yang dapat dimanfaatkan sebagai penyembuhan luka bakar adalah daun pandan (Pandanus amaryllifolius). Ekstrak daun pandan (Pandanus amaryllifolius) memiliki kegunaan sebagai obat luka bakar, namun sulit berpenetrasi kedalam kulit. Kendala ini dapat diatasi dengan memasukan ekstrak daun pandan ke dalam transfersome yang memiliki kemampuan melewati celah pori yang sempit pada kulit. Dilakukan tiga formulasi dengan penambahan ekstrak daun pandan $(0,025 \%)$ dan suspensi transfersome $(1,161 \%)$ dan tanpa penambahan kedua ektrak. Penambahan karbopol 940 digunakan sebagai gelling agent. Evaluasi gel yaitu organoleptik, homogenitas, $\mathrm{pH}$ dan viskositas. Hasil ke tiga formula berwarna putih seulas, tidak berbau, homogen dan tidak terdapat gumpalan. Viskositas formula dengan trasfersome menunjukkan aliran dilatan dan $\mathrm{pH}$ 5,6. Seidaan gel yang dibuat, diharapkan dapat mengatur pelepasan transfersome dan menempel lebih lama sehingga meningkatkan waktu kontak pada kulit yang mengalami luka bakar.

Kata kunci: Gel, Transfersome, Daun Pandan, Luka Bakar
\end{abstract}

\section{DEVELOPMENT OF GEL FORMULATION THAT CONTAINS PANDAN LEAF TRANSFERSOME EXTRACT SYSTEM}

\begin{abstract}
Transfersome has become new trends in developing new strategy for drug delivery. Transfersome has the ability to penetrate into the skin better than the others. Skin burns will form damage which make difficult to penetrate into the skin, thereby prolonging the time and healing process. One of the materials that can be used as a wound healing of Pandanus amaryllifolius leaves. The extract of Pandanus amarullifolius leaf has used as a medicine for burns, but when the healing process of the burn takes a long time. If, Pandan leaf extract is put into a transferome that has the ability to pass through a narrow gap in the skin can be a solution. Transfersome containing pandan leaf extract cannot be used directly to burns, so it can formulate the transfersome that contains pandan leaf extract into gel form. Three formulations
\end{abstract}


are required with Pandan leaf extract $(0.025 \%)$, transfersome suspension extract $(1.161 \%)$ and without both of the two extracts. The addition of Carbopol 940 is used as gelling agent. The gel evaluated was organoleptic, homogeneity, $\mathrm{pH}$ and viscosity. The result showed that three formulas are white, odorless, homogeneous and no lumps. Gel form containing transfersome are then organoleptically tested, gel homogeneity, $\mathrm{pH} 5.6$ and viscosity of the gel. The gel made, is expected to regulate the release of transfersome and stick to it longer so that it increases contact time on burnt skin.

Keywords: Gel, transferosome, Pandanus amaryllifolius, Burns

\section{PENDAHULUAN}

Hambatan terbesar dalam penghantaran rute kulit adalah adanya lapisan stratum korneum pada bagian kulit terluar. Lapisan stratum korneum tersusun secara rapat sehingga sulit ditembus oleh molekul-molekul dari luar (Walve, 2011). Hal ini diperparah dengan adanya luka bakar yang menambah kesulitan obat berpenetrasi melalui rute kulit. Berbagai pendekatan dilakukan untuk meningkatkan penetrasi melewati stratum korneum diantaranya dengan menggunakan transfersome. Transfersome merupakan salah satu sistem penghantaran sediaan transdermal yang berbentuk kantung dengan ukuran nanometer.

Transfersom merupakan nanovesikel yang terdiri dari bagian yang bersifat hidrofil dan hidrofob secara bersamaan yaitu fosfolipid, surfaktan dan air (Walve, 2011). Transfersom dapat menghantarkan obat dengan sifat kelarutan yang bermacam-macam, transfersom juga bersifat elastis sehingga dapat melewati celah yang ukurannya 5 sampai 10 kali lebih kecil tanpa kehilangan bentuknya (Ratnasari, 2106).

Elastisitas dan deformabililitas yang dimiliki transfersom menjadi keunggulannya untuk lebih mudah menembus lapisan kulit. Transfersom yang diformulasikan ke dalam sediaan gel diharapkan mampu meningkatkan penetrasi ekstrak daun pandan berpentasi dan menyembuhkan kulit yang mengalami luka bakar.

Kata " gel " berasal dari "gelatin" cairan seperti bahan padat yang tidak mengalir, tetapi elastis dan mempertahankan beberapa karakteristik cair. Gel umumnya lebih kaku dari jeli karena gel mengandung lebih banyak ikatan kovalen, kepadatan ikatan fisik yang lebih tinggi, atau lebih sedikit cairan. Beberapa sistem gel berwujud sejernih air, dan yang lain keruh karena bahan-bahannya mungkin tidak sepenuhnya terdispersi secara molekul (larut atau tidak dapat larut), atau mereka dapat membentuk agregat (Rathod, 2015).

Gel merupakan sistem semisolid yang tersusun atas dispersi molekul kecil atau besar dalam pembawa berair seperti jeli dengan penambahan bahan pembentuk gel. Bahan pembentuk gel yang dapat digunakan berupa makromolekul sintetik, derivat selulosa dan gum alami (Allen LV. 2013).

Gel dapat diklasifikasikan dalam ke dalam 2 bentuk menurut fasa koloidal nya, yaitu (Prajapati TS. 2011) :

1. Gel fasa tunggal adalah gel yang memiliki makromolekul yang terdistribusi merata di seluruh cairan tanpa batas yang tampak antara makromolekul yang terdispersi dan cairan.

2. Sistem dua fase merupakan massa gel yang terdiri dari flokul partikel kecil yang terpisah, sering kali disebut magma. Contoh: susu magnesia 
(magma magnesia) yang terdiri dari endapan magnesium hidroksida

Gel transfersome termasuk ke dalam gel fasa tunggal, dimana gel memiliki maromolekul yang terdistribusi merata diseluruh cairan, tanpa ada batas yang nampak.

Penelitian ini bertujuan untuk mengkarakterisasi gel yang mengandung ekstrak daun pandan dalam sistem transfersome. Karakterisasi dari sistem penghantaran transfersome yang digunakan dalam penelitian ini telah dipublikasi di seminar BICFH 2019. Maka karakterisasi dari gel yang akan dibahas dalam jurnal ini, meliputi pengujian organoleptis, homogenitas, $\mathrm{pH}$ gel, dan pengujian viskositas.

\section{METODE PENELITIAN}

Alat

$\mathrm{pH}$ meter, homogenisizer, cover glass, viscometer.

\section{Bahan}

Transfersome ekstrak daun pandan yang telah dipisahkan dengan bagian cairnya dengan sentrifugator, ekstrak daun pandan kering, karbopol 940, TEA, Popylen Glycol, dan aqua demineralisata bebas $\mathrm{CO}_{2}$.

\section{Pembuatan Transfersome Dengan Ekstrak Daun Pandan}

Transfersome dapat dibuat dengan menggunakan metode hidrasi lapis tipis. Dicampurkan fosfatidilkolin kedelai dan tween 80 sebagai surfaktan (80:20). Kemudian, campuran dilarutkan dengan pelarutnya yaitu kloroform dan metanol
(2:1). Jumlah pelarut yang dimasukan sebanyak dua puluh kali dari campuran fosfatidilkolin kedelai dan tween 80 . Sebanyak $50 \mathrm{mg}$ serbuk ekstrak daun pandan dimasukan ke dalam campuran fosfolipid dan tween 80. Dievaporasi dengan menggunakan rotary evaporator pada suhu $56^{\circ} \mathrm{C}$ dengan kecepatan 75-130 rpm untuk menghilangkan pelarut organik. Selanjutnya, didiamkan selama 24 jam untuk menyempurnakan pembentukan vesikel. Lapisan tipis yang dihasilkan dihidrasi dengan menggunakan larutan dapar posfat $\mathrm{pH} 7,4$ sebanyak $100 \mathrm{ml}$ dengan suhu $56^{\circ} \mathrm{C}$ kecepatan 75 rpm selama 30 menit. Kemudian, disonikasi dengan sonicator bath selama 30 menit.

\section{Pembuatan Gel yang Mengandung Transfersome Ekstrak Daun Pandan}

Pembuatan basis gel dengan cara membasahi carbophol 940 dengan aquademineralisata bebas $\mathrm{CO}_{2}$. Kemudian ditambahkan dengan TEA sampai didapatkan konsistensi yang diharapkan dan diperhatikan $\mathrm{pH} . \mathrm{pH}$ sediaan harus sesuai dengan kriteria $\mathrm{pH}$ untuk sediaan kulit yaitu $\mathrm{pH}$ antara 4,5-6,5. Propylen glycol ditambahkan ke dalam basis gel yang telah terbentuk. Ditambahkan dengan sisa aqua demineralisata bebas $\mathrm{CO}_{2}$. Dihomogenisasikan dengan menggunakan homogenizer kecepatan maksimal 500rpm yang ditingkatkan secara bertahap. Penggabungan transfersom ke dalam basis gel dilakukan dengan homogenizer dengan kecepatan pengadukan $500 \mathrm{rpm}$ salama 30 menit. Formulasi dari gel yang akan dibuat, dapat dilihat pada Tabel 1. 
Tabel 1. Formula Gel

\begin{tabular}{cccc}
\hline Bahan & Formula 1 & Formula 2 & Formula 3 \\
\hline Suspensi transfersome & - & - & $1.161 \%$ \\
ektrak daun pandan & & & \\
TEA & $0.5 \%$ & $0.5 \%$ & $0.5 \%$ \\
Propylen glikol & $12.5 \%$ & $12.5 \%$ & $12.5 \%$ \\
Carbopol 940 & $1 \%$ & $1 \%$ & $1 \%$ \\
Ektrak daun pandan & - & $25 \mathrm{mg}$ & - \\
Aqua ad & $100 \%$ & $100 \%$ & $100 \%$ \\
\hline
\end{tabular}

\section{Evaluasi Gel}

\section{Pengamatan organoleptis}

Pengamatan organoleptis meliputi bau, warna, ada atau tidaknya pemisahan fase.

\section{Homogenitas}

Dilakukan dengan cara meletakan sampel diantara dua kaca objek kemudian dilihat dibawah sinar melihat ada atau tidaknya partikel.

\section{Pengukuran pH}

Pengukuran $\mathrm{pH}$ dengan menggunakan $\mathrm{pH}$ meter yang telah dikalibrasi terlebih dahulu.

\section{Viskositas}

Dilakukan dengan menggunakan viskometer Brookfield dengan kecepatan mulai 0,$5 ; 2 ; 5 ; 10$; dan $20 \mathrm{rpm}$, lalu balik $20 ; 10 ; 5 ; 2 ; 0,5$ rpm. Data yang diperoleh diplotkan terhadap tekananan geser $\left(\right.$ dyne $\left./ \mathrm{cm}^{2}\right)$ dan kecepatan geser (/sec).

\section{HASIL DAN PEMBAHASAN Pengamatan Organoleptis}

Hasil pengujian secara organoleptik memberikan hasil seperti yang ditampilkan pada Tabel 2.

Tabel 2. Hasil Pengujian Organoleptis

\begin{tabular}{cccccccccc}
\hline $\begin{array}{c}\text { Minggu } \\
\text { ke- }\end{array}$ & \multicolumn{3}{c}{ Basis gel } & \multicolumn{4}{c}{ Gel ekstak daun pandan } & \multicolumn{3}{c}{ Gel transfersome } \\
& \multicolumn{1}{c}{ Warna } & Bentuk & Bau & Warna & Bentuk & Bau & Warna & Bentuk & Bau \\
\hline 0 & Bening & Gel & Tidak & Coklat & Gel & Daun & Putih & Gel & Tidak \\
& & semisolid & berbau & muda & semisolid & pandan & seulas & semisolid & berbau \\
1 & Bening & Gel & Tidak & Coklat & Gel & Daun & Putih & Gel & Tidak \\
& & semisolid & berbau & muda & semisolid & pandan & seulas & semisolid & berbau \\
2 & Bening & Gel & Tidak & Coklat & Gel & Daun & Putih & Gel & Tidak \\
& & semisolid & berbau & muda & semisolid & pandan & seulas & semisolid & berbau \\
3 & Bening & Gel & Tidak & Coklat & Gel & Daun & Bening & Gel & Tidak \\
& & semisolid & berbau & muda & semisolid & pandan & & semisolid & berbau \\
4 & Bening & Gel & Tidak & Coklat & Gel & Daun & Bening & Gel & Tidak \\
& & semisolid & berbau & muda & semisolid & pandan & & semisolid & berbau \\
\hline
\end{tabular}




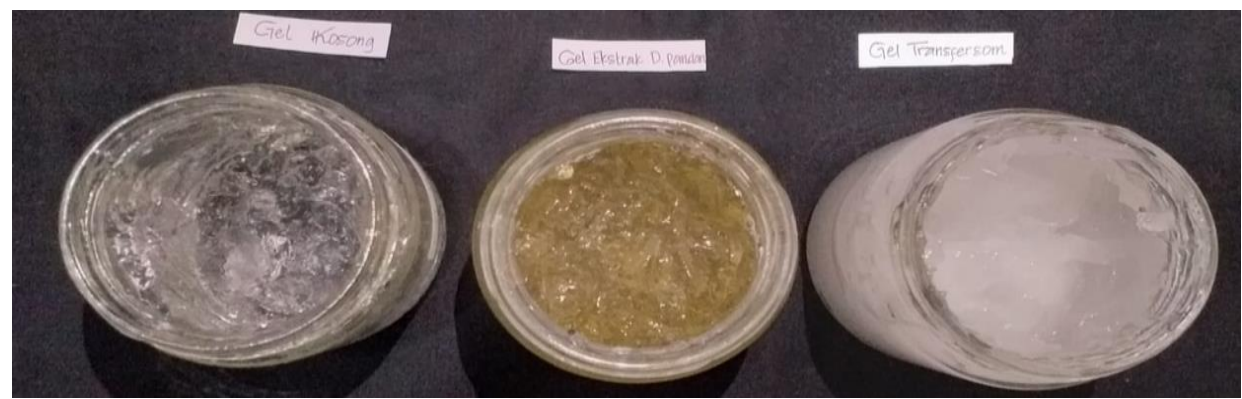

Gambar 1. Gel Basis; Gel ekstrak daun pandan; dan Gel Transfersome

Gel trasfersome memiliki warna putih seulas pada minggu 1 dan pada minggu ke 4 tampilannya menjadi bening. Penampilan gel transfersome ini, menyamai tampilan bening dari pada tampilan basis.

Sedangkan tampilan gel yang ditambahkan ekstrak daun pandan memiliki tampilan berwarna coklat muda. Dan memiliki bau atau aroma khas daun pandan. Gambar 1 menunjukkan tampilan dari gel yang telah dibuat.

\section{Homogenitas}

Pengujian ini dilakukan untuk mengetahui apakah gel yang dibuat sudah homogen atau tidak. Gel yang mengandung transfersome dikhawatirkan tidak homogen dan terasa berpasir, akan tetapi hal tersebut tidak terbukti. Gel transfersome memiliki tampilan yang homogen pada pengujian homogenitas, karena transfersome yang ditambahkan pada gel, telah berukuran nanometer.

\section{Pengukuran pH}

Gel yang mengandung transfersome memiliki $\mathrm{pH}$ pada rentang 5,6 sedangkan sistem transfersome ekstrak daun pandan memiliki $\mathrm{pH} 7,4$ karena dalam formulasinya terdapat buffer $\mathrm{pH}$ 7,4. Akan tetapi ketika diformulasikan ke dalam gel, $\mathrm{pH}$ gel tersebut 5,6. Hal ini dikarenakan $\mathrm{pH}$ dari Karbopol 940 bersifat asam, antara pH 24 (Qushawy, 2018)

\section{Viskositas}

Konsistensi pada sediaan farmasi sangatlah penting, terutama pada gel. Grafik viskositas dari gel transfersome ditunjukkan pada Gambar 2. Gel yang diharapkan adalah gel yang mudah dituang, tetapi gel tersebut dapat tetap mempertahankan bentuknya ketika disimpan.

Karbopol 940 merupakan suatu gelling agent yang sangat baik. Karbopol 940 menunjukkan efek yang signifikan dalam meningkatkan viskositas (Nariswari, 2011) 


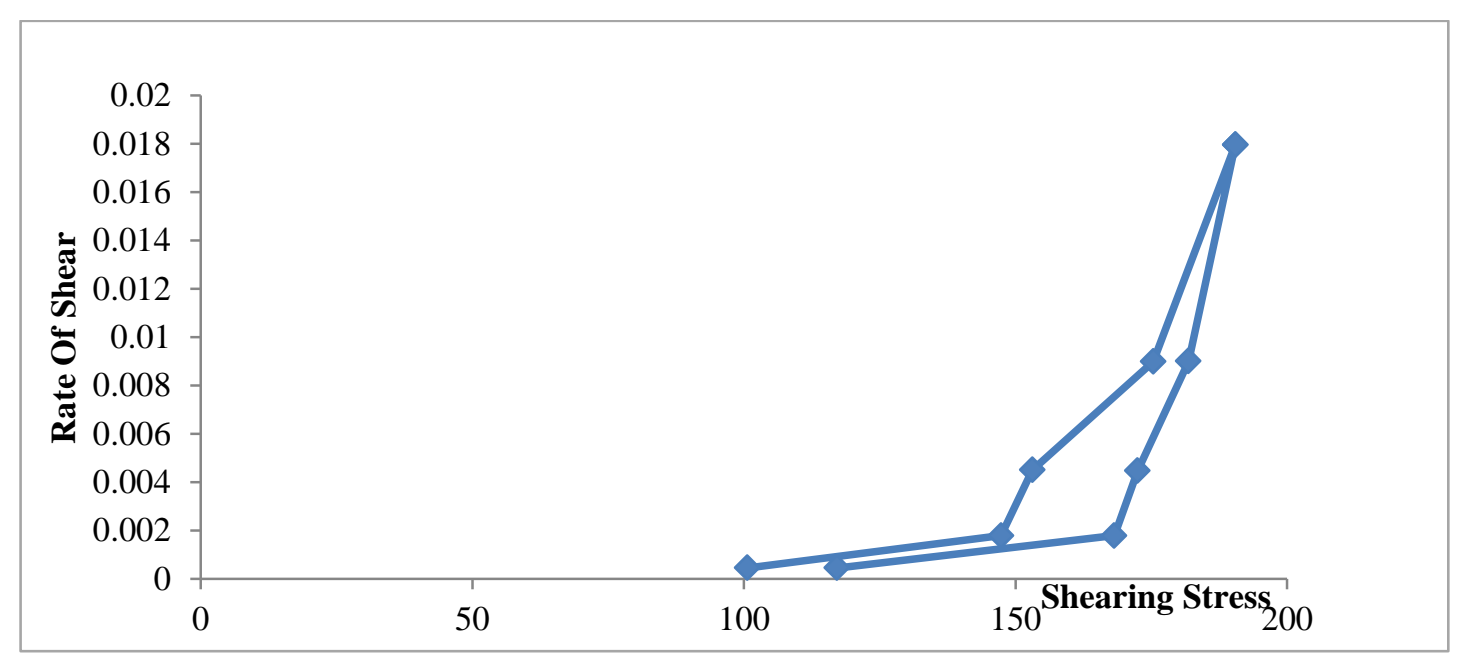

Gambar 2. Grafik Viskositas Gel Transfersome

\section{KESIMPULAN}

Kesimpulan yang dapat diambil dari penelitian ini adalah transfersome dapat diformulasikan dengan baik ke dalam bentuk sediaan gel. Karbopol 940 digunakan sebagai gelling agent yang meningkatkan kestabilan bentuk dari gel ketika disimpan dalam waktu yang cukup lama. pH sediaan gel adalah 5,6.

\section{REFERENSI}

Allen, L.V., Popovich, N.G. \& Ansel, H.C. 2013. Ansel bentuk sediaan farmasetis dan sistem penghantaran obat. Penerbit EGC. Jakarta.

Nariswari, F.A. 2011. Efek carbopol 940 sebagai thickening agent dan gliserol sebagai humectant terhadap sifat fisis shampoo ekstrak kering the hijau (Camellia sinensis L.): aplikasi desain faktorial. Skripsi Universitas Sanata Dharma.

Prajapati, T.S., Patel, C.G. \& Patel, C.N. 2011. Transfersome : A Vesicular Carrier System for Transderma
Drug Delivery. Asian J. Biochem. Pharm. Res. 1(2):138-143.

Qushawy, M., Nasr, A., Alhaseeb, M.A. \& Swidan, S. 2018. Design, Optimization and Characterization of a Transfersomal Gel Using Miconazole Nitrate for the Treatment of Candida Skin Infections. Pharmaceutics. 10(1): 26.

Ratnasari, D. \& Anwar, E. 2016. Karakterisasi nanovesikel transfersome sebagai pembawa "rutin" dalam pengembangan sediaan transdermal. Jurnal Farmamedika. 1(1):1-7.

Rathod, H., \& Mehta, D. 2015. A Review on Pharmaceutical Gel. Acta Scient. Int. J. Pharm. Sci. 1(1):3347.

Walve, J.R., Bakliwal, S.R., Rane, B.R. \& Pawar, S.P. 2011. Transfersomes: A Surrogated Carrier for Transdermal Drug Delivery System. Intl. J. App. Biol. Pharm. Tech. 2(1):204-213. 